\title{
The Relation between Academic Procrastination of University Students and Their Assignment and Exam Performances: The Situation in Distance and Face-to-Face Learning Environments
}

\author{
M. Betul Yilmaz \\ Correspondence: M. Betul Yilmaz, Yildiz Technical University, Faculty of Education, Computer Education and \\ Instructional Technologies Department, Istanbul, Turkey.
}

\author{
Received: July 18, $2017 \quad$ Accepted: August 16, $2017 \quad$ Online Published: August 17, 2017 \\ doi:10.11114/jets.v5i9.2545 URL: https://doi.org/10.11114/jets.v5i9.2545
}

\begin{abstract}
The relation between assignment and exam performances of the university students and their academic procrastination behaviors in distance and face-to-face learning environments was investigated in this study. Empirical research carried out both in face-to-face and online environments have generally shown a negative correlation between academic procrastination and academic performance. However, the effect of academic procrastination on assignments in distance learning setting has not been analyzed extensively. To understand the interaction between academic procrastination and the learning environment; assignment and exam performances of eighty-eight university students in face-to-face (FtF) and distance learning (DL) environments were investigated. According to the findings of the study, students' academic procrastination and assignment scores were negatively correlated in both environments but especially in DL setting. Contrary to this, academic procrastination and exam scores were correlated to each other only in FtF environment. On the other hand, there was no correlation between total assignment and exam scores for DL group, while a medium positive correlation was found in FtF group. The findings of binary logical regression analysis demonstrated that predictive value of the DL environment for assignment score is much stronger than academic procrastination behavior of students.
\end{abstract}

Keywords: academic procrastination, formative assessment, assignment performance, distance learning university students

\section{Introduction}

\subsection{Introduce the Problem}

In the last few decades, there has been an evolution from face-to-face learning-teaching environments to technology integrated face-to-face, blended, distance and open learning environments. Despite this shift, fundamental phases of teaching (analysis, planning, delivering content, doing activities and evaluation) continue to take place in all of these environments. Regardless of the level of technology integration, students are expected to perform tasks such as preparing term projects with deadlines, preparing for exams, or completing daily or weekly reading assignments (Uzun Özer, 2009). Assignments can be seen as a tool to shape how much, how, and what (the content) students learn (Scouller, 1998). Fulfilling these tasks with deficiencies or not being able to complete them before the deadline often results in poor academic performance. Academic procrastination is one of the factors that causes this situation (Akinsola, Tella, \& Tella, 2007; Asarta \& Schmidt, 2013; Balkıs, Duru, Buluş, \& Duru, 2006; Klingsieck, Fries, Horz, \& Hofer, 2012; Michinov, Brunot, Le Bohec, Juhel, \& Delaval, 2011, Moon \& Illingworth, 2005, Perrin et al., 2011; You, 2015).

Procrastination refers to 'the lack of intention or willingness to take action' (Ryan \& Deci, 2000 as cited in Rakes \& Dunn, 2010, p. 80) that is typically observed in the form of intentional and habitual delay of tasks (Elsworth, 2009). It indicates a discrepancy between a person's intention to take action and the observed performance of that action (Blunt $\&$ Pychyl, 2005). Steel (2007, p.66) defines procrastination as 'to voluntarily delay an intended course of action despite expecting to be worse off for the delay'.

Recently, there has been ample research on procrastination, which is a pervasive phenomenon (Klingsteick, Fries, Horz \& Hofer, 2012). Academic procrastination in schools is frequently observed in tasks such as preparing for examinations, doing homework, and completing projects. Steel (2007) found that more than $80 \%$ of undergraduate students are 
involved in procrastination and up to $50 \%$ of them are consistent procrastinators. It is estimated that this rate is approximately $50 \%$ in Turkish university students (Uzun Özer et al., 2009). To make things worse, the Internet is a powerful attention distractor owing to its online and entertaining applications (Thatcher, Wretschko, \& Fridjhon, 2008). Parallel to the changing technology and learning environments, procrastination in e-learning requires special attention (You, 2015).

\subsection{Explore Importance of the Problem}

Academic success for undergraduates is linked to study goals and effective management of study time (Stewart, Stott, \& Nuttall, 2016). You (2015) reports that late submission or absence of assignments is related to low level course achievement. Contribution of assignments in learning as a formative assessment tool is non-negligibly valuable. However, they may not be seen as important as exams by students when it comes to passing the course. Making the best of assignments given for formative assessment purposes should be considered as an opportunity by students to see and complete their weaknesses and improve what they learn. Assignments should be managed accurately in order to provide maximum efficiency during the learning process. Nonetheless, studies on procrastination have focused on the causes of this behavior and to some degree how it is related to school achievement; however, assignment achievement has not been fully researched (Hong \& Milgram, 2000). For this reason, correlation of academic procrastination with assignment and exam performances of students in different learning environments is the focus of this research.

\subsection{Literature Review}

Procrastination is common in academic contexts, especially in environments where students have to meet deadlines for assignment completion, which necessitates students' time and concentration (Gafni \& Geri, 2010). This situation requires students to manage their time constantly throughout the semester. Inadequate self-regulation, which manifests itself as procrastination, is connected to a variety of negative study behaviors (Stewart, Stott, \& Nuttall, 2016). However, since procrastinators have relatively short amounts of time for fulfilling tasks, they rush to complete their work (You, 2015). Indeed, in his meta-analysis of procrastination research, Steel (2007) reported that strong, consistent predictors of procrastination appeared in the forms of task aversion and task delay. Similarly, Balkıs, Duru, Buluş, \& Duru (2006) demonstrated that negative time management is among the significant predictors of academic procrastination tendency.

On the other hand, procrastination does not simply result from a deficit in time management or ineffective study habits; it involves a complicated interaction among behavioral, affective, and cognitive elements (Rothblum, 1994 as cited in Rakes \& Dunn, 2010)). One of the most commonly encountered components among them is self-regulation. From a conceptual viewpoint, procrastination and self-regulation are closely related constructs (Tuckman, 2005). The inclination to procrastinate is very frequently attributed to an insufficiency in self-regulation processes (Michinov et al., 2011; Yamada et al, 2016). Elsworth (2009) reports that conceptualizations of procrastination resulting from self-regulation failure have been substantially supported by empirical research. For example, in his comparative study with high, moderate, and low procrastinators; Tuckman (2002) found a negative correlation between self-regulation and procrastination; the more the students were self-regulated, the less they procrastinated. Similarly, in their study, Rakes \& Dunn (2010) found that when students lack intrinsic motivation to learn and have diminished self-regulation, there is an increase in procrastination.

Schunk and Zimmerman (1998 as cited in Rakes \& Dunn, 2010) suggest that self-regulated learning strategies should be more important considering the increasing number of students' participation in distance learning environments where instructors do not physically teach. These environments require more autonomous students (Rakes \& Dunn, 2010) and in these environments, teachers should be aware of the tendency of their students to procrastinate (Delaval, Michinov, Le Bohec, \& Le Hénaff, 2017). McElroy \& Lubich, (2013, p. 85) states that 'the nature of online classrooms increases the need for students to have greater intrinsic motivation and to initiate the learning process, thereby exacerbating the tendency to delay for many students in online classrooms'.

Regarding the procrastination and achievement, both coherent and contradictory findings are seen in literature in DL setting. For example, the study by Michinov et al. (2011) demonstrated that learners who are most likely to procrastinate are the ones who perform the worst in online learning environments. Yet, in another study, while procrastination in online sections was negatively correlated with exam scores, the same correlation was not observed in FtF sections (Elvers, Polzella, \& Graetz, 2003). However, in another study by Romano et al.. (2005), all students followed the same class syllabus and schedule, and they took the same objective-style examinations in distance and blended learning. According to the findings of their study, 'students with live instructors (blended) and less transactional distance tended to procrastinate more than total distance students with greater transactional distance' (Romano et al., 2005, p. 303). Their findings contradict with the expectations based on transactional distance (see: Moore \& Kearsley, 2011).

Since online students do not meet with their peers and instructors in regular classes, they are more likely to procrastinate and squeeze more work into less time, which leads to less effective outcomes (Rakes \& Dunn, 2010). It 
appears as if students perceive such unstructured distance-learning environment as an excuse to procrastinate (Klingsieck, Fries, Horz, \& Hofer, 2012). There has been more research on procrastinating and non-procrastinating students in online, blended and face-to-face environments in the last decade (Geri, Gafni, \& Winer, 2014; Klingsieck, Fries, Horz, \& Hofer, 2012; Michinov et al., 2011; Rakes \& Dunn, 2010; Romano, Wallace, Helmick, Carey, \& Adkins, 2005; Yamada et al., 2015; You, 2015). Some part of these studies shows that procrastinators are more disadvantaged than non-procrastinators in DL in terms of their academic achievement.

The students, who have the habit of procrastination, usually deliver the assignment on time; however, they manage this with an increasing performance towards the end of the time instead of using time effectively (Steel, 2002). For this reason, chronic and academic procrastination are often connected with detrimental behaviors and outcomes such as low academic performance (Uzun Özer, Demir, \& Ferrari, 2009), submission of assignments after the deadline and cramming (Klassen, Krawchuk, \& Rajani, 2008).

\subsection{Research Problems}

Depending the literature and the importance of the study, the following research problems have been raised:

1. Is there a correlation between academic procrastination scores and total assignment scores of students in face-to-face and distance learning environments?

2. Is there a correlation between academic procrastination scores and exam scores of students in face-to-face and distance learning environments?

3. Is there a predictive relation between academic procrastination, total assignment, and exam scores of students in distance learning environments?

\section{Method}

Within the following chapter, the information on how the study was conducted is provided, including descriptions of the participants, data collection tools and the procedure.

\subsection{Research Design}

In this study, comparative survey method was employed as a descriptive research design model. Two different learning environments were arranged for the course in which the study was conducted: face-to-face (FtF) (group 1) and distance learning (DL) (group 2). The research was conducted for 15 weeks. In each group, participants' academic procrastination behaviors, assignment scores, and exam scores were used as independent variables.

\subsection{Participant Characteristics}

Participants of the research were students at Faculty of Education, Computer and Instructional Technologies Education Department of a state university in Istanbul, Turkey and taking "Information Technologies in Education I" course during 2015-2016 academic year. Course content included usage of presentation, word processing, and electronic worksheet programs for educational purposes. Since 12 out of 100 students enrolled in the course were excluded from the study due to incompletion of the course and unwillingness to complete the data collection tool, a total of 88 students participated in the study. $79(89.8 \%)$ of the students were freshmen, eight $(9.1 \%)$ of them were sophomores and one of them $(1.1 \%)$ was junior. 32 of the participants $(36 \%)$ were female and 56 of them (64\%) were male. Ages of students ranged from 17 to 30 and the mean age was 19.3 .

\subsection{Procedure}

As mentioned before, FtF (group 1) and DL (group 2) environments were arranged for the course in which the study was conducted. Participants of the study enrolled in one out of the two different groups of the course over the student management system of the university at the beginning of semester. Whether the courses would be given FtF or through DL was shared with the students prior to enrollment. Only 12 of the students in the second group stated that they particularly wanted to receive the course online. However, 28 students had to take the course in DL environment owing to the full capacity of FtF course. Students took other courses together in FtF environment during the semester.

The course content included using presentation, word processing and electronic worksheet programs, and outcomes regarding using these programs were determined. Both groups followed the same syllabus and were delivered the same content concurrently week by week. The content also consisted drill and practice activities related to the outcomes. These activities had been done by group 1 students in the computer lab. Students in group 2 did the same activities on the LMS.

The first group took the course in a FtF environment at computer lab and feedbacks for drill and practice activities were supplied promptly. Course was scheduled to be 2 hours per week for this group. The second group took the course in DL environment. In this group, course materials prepared as videos, visual aided texts, and presentation files were delivered to the students by allowing access on a weekly basis via learning management system (LMS). The 
recommended time to spend on online course materials was approximately two hours per week as well. As a limitation of the study, there were no live classrooms or active discussion boards to allow interaction between students in DL environment. Students in group 2 asked their questions and were responded via LMS, although feedback demands very occasionally occurred in this group.

Students taking the course were requested to send four different assignments (in a manner not to exceed deadlines) related to course content through electronic mail (group 1) or by uploading them to LMS (group 2) through the semester. For assessments, no questions were allowed and no feedback was provided in both groups before deadline. At the end of the semester, students in both groups took a hands-on exam at the same day and same place. Students were told that their scores from the assignments and exam would be reflected in their passing scores in equal weights.

\subsection{Data Collection Tools}

The first data collection tool used in this research is the "Academic Procrastination Scale" developed by Çakıcı (2003). The Academic Procrastination Scale is a five point Likert scale consisting of 19 items with seven reverse items. Score range for the scale is 19-95 and high score means high academic procrastination behavior. Cronbach alpha $(\alpha)$ coefficient for internal consistency of the original scale has been calculated as .92 (Çakıc1, 2003). Cronbach alpha $(\alpha)$ has been found as .91 in this study. The scale was administered to students at the beginning of the procedure and took around seven minutes to complete.

The second data collection tool consisted of four different assignments developed according to the outcomes of the course. One of the assignments was creating a presentation, two of them involved using word processing, and one of them required using electronic worksheet programs. Each assignment had a theme within its own integrity and contained multiple behaviors related to the determined outcomes. Contents of the assignments and assignment scoring criteria have been developed by the researcher and finalized by opinions of two expert lecturers in the field. Assignments were announced to the students in both groups to be submitted electronically on pre-determined deadlines. All submitted assignments were graded by two teaching assistants according to determined scoring criteria. Maximum total score that can be obtained from four assignments was 100 .

The third data collection tool was a hands-on exam regarding presentation, word processing, and electronic worksheet programs. The exam, which was developed by the researcher based on course outcomes, consisted of 11 questions. Four questions were related to presentation, four questions were related to word processing, and three of them were related to using electronic worksheet programs. For each question, students were asked to complete some tasks on the computer, which composed of several behaviors related to programs mentioned above. An answer key was also developed in order to guide the marking process of the exam. In the answer key, required responses were described in detail and every steps of tasks were graded for each answer. Face and content validity of the exam was assessed and approved by two expert lecturers. These experts also confirmed the marking scheme of the answer key. The exams were taken in a proctored setting. Both groups were separately tested in a computer lab in the same day in successive sessions, within 40 minutes in total per session. Answers given by the students were promptly scored by the researcher and two teaching assistants according the answer key during each session. The score that could be obtained from the exam ranged between 0 and 100 .

\subsection{Analysis of Data}

SPSS 21 was used to analyze the data. Although normality requirements for academic procrastination scores were met, analyses made on total assignment scores and exam scores demonstrated non-normal negatively skewed distribution. Therefore, non-parametric tests including Mann Whitney U test, Spearman's correlations test, and binary logical regression analysis were performed in the study.

\section{Results}

In this section, results of the statistical analyses related to research problems are presented. Descriptive statistical analyses were conducted prior to correlational analyses. Descriptive statistics of 48 students taking courses in FtF environment and 40 students taking courses in DL environment are presented in Table 1.

Table 1. The descriptive statistics of academic procrastination scores, total assignment scores and exam scores

\begin{tabular}{|c|c|c|c|c|c|c|c|c|c|c|c|}
\hline \multirow{2}{*}{ Variables } & \multicolumn{4}{|c|}{ Group $1(\mathrm{FtF})(N=48)$} & \multicolumn{4}{|c|}{ Group $2(\mathrm{DL})(N=40)$} & \multirow{2}{*}{$\begin{array}{c}\text { Mann } \\
\text { Whitney U }\end{array}$} & \multirow{2}{*}{$\mathrm{p}$} & \multirow{2}{*}{$\mathrm{r}$} \\
\hline & Min & Max & $\bar{x}$ & $\mathrm{Sd}$ & Min & Max & $\overline{\mathbf{x}}$ & $\mathrm{Sd}$ & & & \\
\hline Academic Procrastination Score & 32 & 76 & 49.13 & 10.66 & 28 & 85 & 51.99 & 12.49 & 807.500 & .201 &, 14 \\
\hline Total Assignment Score & 0 & 100 & 78.62 & 23.67 & 0 & 92.63 & 68.06 & 23.98 & 580.500 & .001 & ,34 \\
\hline Exam Score & 31 & 100 & 81.17 & 17.96 & 41 & 100 & 81.23 & 13.40 & 858.500 & .508 &, 14 \\
\hline
\end{tabular}


As seen in Table 1, academic procrastination scores of the participants ranged between 28 and 85 . It is remarkable that maximum and average values of academic procrastination scores of group 2 are higher than group 1. However, Mann Whitney $U$ test analysis demonstrated that there is no statistically significant difference between academic procrastination scores in terms of groups $(\mathrm{U}=807.500 ; \mathrm{p}=.201, \mathrm{r}=0.14)$.

According to Table 1, average of total assignment scores of students is 78.62 for group 1 and 68.06 for group 2 . Minimum score is zero (that means none of four assignments were sent within the deadline) in both groups and unlike the students in group 1, there are no students who could take full score (100) in group 2. Mann Whitney U test analysis demonstrated that difference between total assignment scores of the groups is statistically significant with a medium effect size ( $U=580.500 ; \mathrm{p}=.001, \mathrm{r}=0.34)$. Regarding the results, the median score of total assignment scores decreased from $\mathrm{FtF}$ environment to $\mathrm{DL}$ environment. These results raise the question of whether taking the course in $\mathrm{DL}$ environment created a negative impact on the total assignment scores of the students.

Findings in Table 1 show that students' average exam scores are 81.17 and 81.23 for group 1 and group 2, respectively. While minimum exam scores for group 1 and group 2 are 31 and 41 respectively, maximum exam score for both groups is 100. Mann Whitney $U$ test analysis demonstrated that there is no statistically significant difference between exam scores of the groups $(\mathrm{U}=-858.500 ; \mathrm{p}=.508, \mathrm{r}=0.14)$. According to these results, average scores students obtained from the exam does not differentiate depending on taking the course FtF or through DL.

\subsection{Correlational Analyses}

Spearman's correlational analyses were carried out to understand the relations among 'academic procrastination score', 'total assignment score' and 'exam score' variables. Scatterplots reviewed prior to the analysis demonstrated that linearity requirement for each variable was satisfied. Spearman's correlation analysis was used since the values of academic procrastination scores in dataset did not satisfy normal distribution criteria. Results of the analyses performed individually for group 1 and group 2 are presented in Table 2.

Table 2. The correlation between academic procrastination score, total assignment score and exam score

\begin{tabular}{|c|c|c|c|c|c|c|}
\hline \multirow[t]{2}{*}{ Variables } & \multicolumn{3}{|c|}{ Group $1(\mathrm{FtF})(N=48)$} & \multicolumn{3}{|c|}{ Group $2(\mathrm{DL})(N=40)$} \\
\hline & $\begin{array}{c}\text { Academic } \\
\text { Procrastination } \\
\text { Score }\end{array}$ & $\begin{array}{l}\text { Total } \\
\text { Assignment } \\
\text { Score }\end{array}$ & $\begin{array}{l}\text { Exam } \\
\text { Score }\end{array}$ & \begin{tabular}{|c|} 
Academic \\
Procrastination \\
Score
\end{tabular} & $\begin{array}{c}\text { Total } \\
\text { Assignment } \\
\text { Score }\end{array}$ & $\begin{array}{l}\text { Exam } \\
\text { Score }\end{array}$ \\
\hline Academic Procrastination Score & - & $-.295^{*}$ & $-.316^{*}$ & - & $-.367^{*}$ & .176 \\
\hline Total Assignment Score & $-.295^{*}$ & - & $.389^{* *}$ & $-.367^{*}$ & - & .216 \\
\hline Exam Score & $-.316^{*}$ & $.389^{* *}$ & - & .176 & .216 & - \\
\hline
\end{tabular}

$* p<.05$ level two-tailed, **p<.01 level two-tailed

When Table 2 is examined, it can be seen that inter-correlations among three variables ranged from .244 to .589 for groups. First and foremost, there is a negative correlation between academic procrastination and total assignment scores for both $\mathrm{FtF}$ and DL groups (rho= -.30; $<<.05 ;$ rho $=-.37 ; \mathrm{p}<.05$ respectively), furthermore this correlation is stronger for DL group than FtF group. On the other hand, correlation findings for academic procrastination and exam scores of two groups are not concordant. While a small negative correlation $(\mathrm{rho}=-.32 ; \mathrm{p}<.01)$ was found for $\mathrm{FtF}$ group, for $\mathrm{DL}$ group there was no significant correlation $(\mathrm{rho}=.18 ; \mathrm{p}>.05)$. A similar situation was also observed for total assignment and exam scores of groups. For FtF group there was a moderate positive correlation (rho= .39 ; p<.01) between total assignment and exam scores, yet a significant correlation ( $\mathrm{rho}=.22 ; \mathrm{p}>.05)$ was not found for DL group.

To test the statistical significance of the difference between two groups' correlation coefficients, the observed value of $\mathrm{z}$ was calculated for each variable pairs (Pallant, 2007). As the first step in the comparison process, all rho values were converted to z' values, and for each z' pairs $z_{\mathrm{obs}}$ values were calculated by using Fisher's z-transformation formula. The results show that significance of the difference between two correlation coefficients in FtF and DL groups were not significant for academic procrastination and total assignment score peers and total assignment and exam score peers. On the other hand, the correlation coefficients of academic procrastination and exam scores were statistically significant for both FtF and DL groups.

These different and contradictory results in Table 2 demonstrate that in FtF environment; students' academic procrastination, total assignment, and exam scores are slightly related to each other. On the contrary, in DL environment, the only correlation is observed between academic procrastination and total assignment scores. Hence, it was thought that academic procrastination behavior and the learning environment may predict total assignment score and thus regression analysis was performed. 


\subsection{Binary Logistic Regression}

Since total assignment scores of participants did not exhibit normal distribution, in order to see to how independent variables (academic procrastination: scale; learning environment: categorical) predict these scores, binary logistic regression was carried out. Binary logistic regression analysis is an alternative method to logistic regression analysis that allows categorically and continuously scaled variables to predict any categorically scaled criterion (King, 2008). It can be used when the assumptions of logical regression analysis such as normality or common covariance conditions are not met (Pallant, 2007).

In order to use in binary logistic regression, the variable total assignment score which will be predicted was recoded into categorical 'assignment score level' variable. To this end, "mean $+1 / 4$ *standard deviation" was defined as threshold to diverse 'high' (=0) level total assignment scores, and the remaining scores were coded as 'low' (=1). After recoding, prior to starting binary logistic regression, suitability of the dataset for this analysis was checked as summarized below.

First, for all categorical variable pairs, it was ensured that frequency expected in all cells was greater than 1 and number of cells where expected frequency was less than 5 did not exceed 20\% (Çokluk, 2010). Following this, Mahalanobis distances were calculated for academic procrastination scores, and multivariate outlier presence was sought (Pallant, 2007). Depending on the number of independent variable, which is 2 , it was seen that there was no outlier whose Mahalanobis distance exceeded 13.8 (Akbulut, 2010, p. 157). With regard to the values in multicollinearity diagnosis table, it was observed that tolerance values did not approach 0 (Pallant, 2007) and variable increase factors (VIF) were smaller than 10 (Akbulut, 2010, s. 75). At the end of these controls, it was concluded that the data set was suitable for binary regression analysis. A binary regression analysis was conducted to predict total assignment score level for 88 participants, using 'type of learning environment (group)' and 'academic procrastination score' as predictors. 'Stepwise forward' method was used to predict dependent variable in the analysis.

The full model containing both predictors was statistically significant, $\chi_{(2, N=88}^{2}=15.799, p>.001$, indicating that the model was able to distinguish between students who had and did not have high total assignment scores. Hosmer and Lemeshow goodness-of-fit test regarding the suitability of the model $\left(\chi_{(2, N=88)}^{2}=14.290, p>.05\right)$ was not concluded a significancy (2000); therefore goodness index of the model was sufficient (Çokluk, 2010). The model as a whole explained between 16.4\% (Cox and Snell R square) and 22.2\% (Nagelkerke R square) of the variance in total assignment score level, and correctly classified $70.5 \%$ of cases $(83.0 \%$ for higher assignment score and $51.4 \%$ for lower assignment score). R square values indicated that learning environment (group) and academic procrastination explained $16.4 \%$ to $22.2 \%$ of difference for total assignment score level, which mean there is a low relationship between prediction and grouping. $\beta$ parameters of the model obtained through this analysis and Wald statistics, degrees of freedom, significance levels and odds ratio values are given in Table 3.

Table 3. Logistic Regression Predicting Total Assignment Score

\begin{tabular}{lcccccccc}
\hline & & & & \multicolumn{4}{c}{ Odds $95.0 \%$ C.I for Odds Ratio } \\
$N=88$ & $\beta$ & S.E. & Wald & df & Sig. & Ratio & Lower & Upper \\
\hline Group (1) & -1.141 & .479 & 5.673 & 1 & .017 & .320 &, 125 &, 817 \\
Procrastination & .062 & .023 & 7.506 & 1 & .006 & 1.064 & 1,018 & 1,112 \\
Constant & -2.979 & 1.193 & 6.241 & 1 & .012 & .051 & & \\
\hline
\end{tabular}

-2 log-likelihood $=70,5$; (1)--> internal value of Ft $F$ group

As shown in Table 3, both learning environment (group) and academic procrastination variables made a statistically significant contribution to the model $(\mathrm{p}=.017 ; \mathrm{p}=.006$ respectively). The weaker predictor of high total assignment score was academic procrastination, recording an odds ratio of 1.064. Odds ratio value lower than 1 indicates a negative, and higher than 1 means a positive relationship (Çokluk, 2010). Hence, when academic procrastination is raised by one unit, the odds ratio is 1.064 times larger. This means that one unit increase in academic procrastination gets the student $6.4 \%((1.064-1) * 100)$ closer to low total assignment score level (internal value $=1$ for the model).

On the other hand, for learning environment (group) variable the odds ratio is .320 times smaller. This indicated that students who participated in FtF learning environment were .32 times likely to have low total assignment score level, controlling for the other predictor in the model. In other words, students in FtF environment moved 68\% ((.320-1)*100) away from low total assignment score level.

In brief, the effect of $\mathrm{FtF}$ environment on low assignment score was $68 \%$ negative while the effect of academic procrastination was only $6.4 \%$ positive. 


\section{Discussion and Conclusion}

The relation between assignment and exam performance of university students and their academic procrastination behavior in distance and face-to-face learning environments was investigated in this study.

\subsection{Academic Procrastination and Assignment Scores}

In the study, students were requested to submit four assignments on four different dates, and correlation analysis findings demonstrated that academic procrastination behavior correlates assignment performance negatively in both environments, although this correlation is stronger for DL group than FtF group. In the literature, there are findings which suggest that task aversion, task delay and negative time management are among the strong, consistent predictors of academic procrastination tendency (Balkıs, Duru, Buluş, \& Duru, 2006; Steel, 2007; Yamada et al, 2016). It is possible that procrastinator learners in this study, especially students in DL group, exhibited unsuccessful time management behaviors in assignments to be completed on four different dates. Within this framework, it can be thought that participants may have done their assignments in a hurry and turned in incomplete or poor assignments and thus displayed low assignment performance.

It is stated that self-regulation connects distance learning and procrastination because distance learning environments demand more self-regulation than traditional university settings (Klingsieck, Fries, Horz, \& Hofer, 2012). According to the findings of this study, although descriptive statistical analyses revealed no significant difference between average academic procrastination scores of both groups, the negative correlation between academic procrastination behaviors and assignment performances of procrastinating students in DL group is higher than the relationship observed in the FtF group. Therefore, it seems possible to correlate the negative academic procrastination-assignment performance relation present in DL group directly with the environment in the study. In this study, the students in FtF group had a chance to meet the instructor face to face every week. This might create an automatic reminder effect to submit their assignments on time. Furthermore, in traditional classes, the obligation to attend lectures is a motivating factor for students to engage with class materials in a regular manner. This at least ensures that they distribute their time proportionally across the term (Rakes \& Dunn, 2010). Similarly, by means of attending the course, the students unavoidably became involved in the class in a regular schedule. Conversely, students in DL group may have easily procrastinated while accessing the learning environment due to their insufficient self-regulatory skills. Therefore, students in distance learning environment may have more insufficient self-regulatory competencies compared to the students in FtF environment.

In a study, Perrin et al. (2011) presented online materials to students in two different forms in their study. The results of their study revealed that when online study material was presented inconsequentially, students usually procrastinated. However, when access to additional study material depended on completing previous study material, the distribution of studying was more even (Perrin et al., 2011). Online materials and assignment topics given in our study were independent from each other. While students in FtF environment may have not realized these disconnections within the natural flow of the course or may have overcome such difficulties, the same may not have been possible for students in DL. Hence, it is possible to consider the continuity of topics for assignments in distance learning in order to enable students to become more aware of the content of the assignments and decrease procrastination behavior.

\subsection{Academic Procrastination, Total Assignment Scores, and Exam Scores}

The findings of this research revealed that correlation between academic procrastination scores and exam scores of students varied depending on the groups. A low negative correlation was found between academic procrastination scores and exam scores of students in FtF environment. Conversely, there was no correlation between procrastination and exam scores for students in DL. Similarly, while there was a medium positive correlation between total assignment and exam scores in FtF group, a significant correlation was not found for DL group. In other words, in the study, while procrastinators in FtF group procrastinated consistently for both assignments and exam, students in DL group did not show a uniform pattern in terms of procrastination. Onwuegbuzie (2004) reported that although $39.4 \%$ of students in a face-to-face learning setting procrastinated over studying for exams, $60 \%$ of them procrastinated on keeping up with weekly assignments. In terms of FtF group, this finding is coherent with our findings. On the other hand, Gilbert et al (2016) reveals that, in an online learning environment, students' exam, homework and quiz performances correlate with each other. However, the students in different learning environments might have used different learning strategies depending on the characteristics of these environments. Klingsieck, Fries, Horz, and Hofer (2012) discovered that the difference between students' academic procrastinations originates from the learning environment and meta-cognitive strategies they use.

On the other hand, Pychyl, Morin, \& Salmon (2000) tested whether exam performances of procrastinating students would be low because of fallacious planning of the time required for studying. However, although high procrastinators began later than low procrastinators and worked less, there was no significant difference between the exam results of both student groups. Pychyl, Morin, \& Salmon (2000) claim that even though students exhibited procrastination 
behavior in studying and despite being a last-minuter, they studied sufficiently and did not ignore the importance of the exam. Parallel to their finding, in our study, although there was a correlation between academic procrastination and total score obtained from four assignments in DL group, there was not such a correlation between academic procrastination and exam scores. When it is thought in parallel with Pychyl, Morin, \& Salmon (2000), it can be considered that students in DL group submitted low quality assignments by not attributing much importance to the deadlines of four different assignments or skipped some of them; on the contrary, they might have taken the exam more seriously and accordingly have exhibited less procrastination behavior and prepared better. According to Geri, Gafner \& Winer (2014), when students have limited attention and time resources, they can procrastinate intentionally and specifically focus on studying for the exam. Hence, Solomon and Rothblum (1984 as cited in Uzun Özer et al, 2009) found that students procrastinated more often when writing term papers $(46 \%)$ than they did when reading assignments $(30 \%)$, studying for exams (28\%), or fulfilling academic (23\%) and administrative (11\%) tasks. Similarly, in another study conducted in FtF environment, Tuckman (1997 as cited in Tuckman, 2005) found that, compared to assignments, frequent tests helped procrastinators to improve their academic performance dramatically that led to a significant increase in their grades. It is possible that students in DL group did not give importance to assignments as much as the exam and they invested in more effort while preparing for the exam. These students might exhibit procrastination behavior much more while preparing their assignments; however, they set this behavior aside while preparing for the exam.

With reference to the aforementioned comment, it can be thought that there may be differences in the way students prepare for the exam in both environments. Students tend to increase their study behavior gradually during the term and they almost demonstrate a burst of studying just before the exam (Schouwenburg \& Groenewoud, 2001). At the beginning of the semester, students may be willing to commit themselves and use their attention resources adequately for learning, during the middle, their learning effort is diminished, toward the end, their effort increases, and right before the exam, they show maximum effort in order to learn the course content (Geri, Gafni, \& Winer, 2014). In other words, procrastination demonstrated curvilinear functions (Moon \& Illingworth, 2005). In their study, Moon and Illingworth (2005) administered five exams at different times to university students in FtF environment. According to the findings, while students' dilatory behavior increased over time, it dropped off drastically toward the end of the term. In our study, only for students in DL group, we might consider an academic procrastination behavior that shows a high tendency during the semester but a fall towards the end of semester that does not affect exam performance adversely. Nevertheless, this curvilineality cannot explain the negative correlation between academic procrastination scores and exam scores of students in the $\mathrm{FtF}$ environment.

An advantage of students in DL group when compared to those in FtF group is that over the LMS they have the opportunity to access all study materials they need to prepare for the exam. As frequently seen in procrastinating students, when they delay beginning to study to the last minute, gathering study material may become difficult or impossible. When we take into the consideration the curvilinear characteristic of procrastination behavior, compared to the procrastinators in DL environment, procrastinators in FtF environment have fewer study materials, which they compiled with their own efforts in order to prepare for the exam. According to the findings of Almatrafi, Islam, Johri, Nagappan, \& Modanlu (2015), a positive correlation exists between students' use of Blackboard and student performance. Similarly, de Jong, Verstegen, Tan, \& O'Connor (2013) state that the absence of online learning materials in $\mathrm{FtF}$ environments can be considered as an advantage for procrastinating students in blended learning environments. Positive correlation between exam scores and total assignment scores of students in FtF environment in this study can be considered as a reflection of this case. It is possible that compared to FtF environment, DL environment offers an advantage to procrastinating students in terms of accessing the study materials for the exam. The third research question of the study revealed findings parallel to this situation.

\subsection{Assignment Score Predictors}

Correlation analysis findings of this research demonstrate that, for both environments, academic procrastination behavior negatively correlates with students' assignment scores. Findings regarding the third problem of the research also showed that both learning environment and academic procrastination behavior has an impact on assignment scores of students. While DL environment predicts low assignment level of students $68 \%$, academic procrastination scores predict only at a ratio of $6.4 \%$. These findings demonstrated that predictive value of the DL environment affects assignment score more than academic procrastination.

Procrastination in the DL environment is considered more detrimental because the responsibility of learning largely belongs to individual learners (You, 2015). Tuckman (2005) proposed that in online settings the lack of supervision and the dependence on learner often leads to high procrastination and low performance, especially among students who have a tendency to procrastinate. Eventually, college students fail or withdraw from online classes due to ineffective time management skills and procrastination (Doherty, 2006). Elvers, Polzella, and Graetz (2003), reported that students in the course heavily accessed to the course web pages either the day before or the actual day of an exam. This means 
that the long period until the exam was not utilized efficiently enough. In a distance course, students tend to have more control over time, place and ways of study, and this offers opportunity for self-management that can cause study procrastination, which in turn may result in cramming (Romano et al., 2005). It is possible that, these types of negative study habits can be handled by using the curvilinear function of procrastination for exams. It can be a solution to send automatic reminders via e-mail in order to stimulate students' interest in taking part in the online exercises (Delaval $e t$ $a l$, 2017). Yet, it is seen that it is not easy to overcome this behavior during the whole semester regularly for a couple of assignments for students in DL.

Findings of this study show that students in DL environment should take special measures to reduce their procrastination behaviors while doing their course assignments. For example, administering tests frequently forced students to make a change and procrastinate less (Palcroft \& Lopez, 2009). According to another study, procrastination behaviors of students regress when tests instead of assignments are given (Tuckman, 1997 as cited in Tuckman, 2005). When the importance of assignments for learning is considered, the solutions for this problem in DL settings should be investigated.

\section{Suggestions}

Rakes \& Dunn (2010) suggest that setting strict schedules for assignment deadlines with regular checkpoints deters students from postponing completion of assignments. Similarly, Stewart et al (2016) recommend the use of a split deadline approach instead of a single one in order to increase students' homework, quiz and exam performances, while Deleval et al (2017) suggest teachers to have the students send them regular reports on their use of digital environment to encourage their students to connect and train earlier. However, in a more detailed study, Bui (2007) worked with high and low procrastinators and used strict and loose assessment methods with them. According to the results of his study, which was performed in a face-to-face environment, high procrastinators in the high evaluation threat group significantly delayed submitting their essays compared with those in the low evaluation threat group (Bui, 2007). On the other hand, in the low evaluation threat group, low procrastinators delayed more than high procrastinators did (Bui, 2007). Findings of his study demonstrate that different assessment arrangements are required for students with varying procrastination levels. Based on our findings, there is a need to investigate whether there are similar differences regarding the schedule and frequency of assessments in DL environments.

Additionally, although the use of the term procrastination in the present study refers to the primary, passive, negative form of procrastination, for some of procrastinators, planned procrastination might associate with positive learning behaviors for high performance (Yamada et al., 2015). Chu and Choi (2005) call the procrastinators who perform high-quality learning outcomes with monitoring their learning behaviors 'active procrastinator'. For these individuals postponing does not always jeopardize their learning (Chu \& Choi, 2005). In this study, active and passive procrastinators were not identified among the students. Therefore, there is a need for experimental research on determining whether DL environment has an impact on leaning to active or passive procrastination behaviors.

Regardless of the nature of learning environments, assignments are an essential component of teaching as a formative assessment tool. Therefore, students are expected to do assignments and projects and show sufficient performance in exams in both traditional and online environments. In her research, in face-to-face environment, Scouller (1998) reports that lower performance in the assignments is associated with employment of surface learning strategies. Depending on the findings of our study, this question should be investigated deeply. Further research should focus on understanding to what extend DL environments drive students to exhibit surface learning approaches.

It is important that students fulfill assignments and projects by allowing adequate time and by not exhibiting procrastination behavior in order to increase their performance. Hence, findings of the study suggested that DL environments have disadvantages in terms of procrastination behavior. In future studies, it is recommended that the factors that create more disadvantages in DL environments than $\mathrm{FtF}$ environments, in terms of academic procrastination, be investigated as well as the measures that can mitigate the effect of these disadvantages.

\section{Acknowledgements}

The author would like to thank to Dr. Suzan Kavanoz, for her valuable contributions to improving the use of English in the manuscript.

\section{References}

Akbulut, Y. (2010). Sosyal Bilimlerde SPSS Uygulamaları. Sık Kullanılan İstatistiksel Analizler ve Açıklamalı SPSS Çözümleri. İstanbul: İdeal Kültür\&Yayınclık.

Akinsola, M. K., Tella, A., \& Tella, A. (2007). Correlates of academic procrastination and mathematics achievement of university undergraduate students. Eurasia Journal of Mathematics, Science \& Technology Education, 3(4), 363-370. http://www.ejmste.com/v3n4/EJMSTE_v3n4_Akinsola_etal.pdf 
Almatrafi, O., Islam, K., Johri, A., Nagappan, K., \& Modanlu, A. (2015). An Empirical Study of Face-to-Face and Distance Learning Sections of a Core Telecommunication course. 2015 ASEE Annual Conference and Exposition. Seattle, Washington. https://doi.org/10.18260/p.23521

Asarta, C. J., \& Schmidt, J. R. (2013). Access patterns of online materials in a blended course. Decision Sciences Journal of Innovative Education, 11(1), 107-123. https://doi.org/10.1111/j.1540-4609.2012.00366.x

Balkıs, M., Duru, E., Buluş, M., \& Duru, S. (2006). Üniversite Öğrencilerinde Akademik Erteleme Eğiliminin Çeşitli Değişkenler Açısından İncelenmesi. Ege Ĕgitim Dergisi, 7(2), 57-73.

http://dergipark.ulakbim.gov.tr/egeefd/article/download/5000004024/5000004540

Blunt, A., \& Pychyl, T. A. (2005). Project systems of procrastinators: A personal project-analytic and action. Personality and Individual Differences, 38(8), 1771-1780. https://doi.org/10.1016/j.paid.2004.11.019

Bui, N. H. (2007). Effect of Evaluation Threat on Procrastination Behavior. The Journal of Social Psychology, 147(3), 197-209. https://doi.org/10.3200/SOCP.147.3.197-209

Çakıcı, D. Ç. (2003). An Examination of the general procrastination behavior and academic procrastination behavior in high-school and university students. Unpublished master thesis. Ankara, Türkiye: Ankara Üniversitesi, Eğitim Bilimleri Enstitüsü.

https://tez.yok.gov.tr/UlusalTezMerkezi/TezGoster?key=ePX_SaJ0b35Gq45swKG31FchOJ7SEwpzCfLKc7PZzIa DaCMSR7IFIcAyXeE2LkmN

Chu, A. H., \& Choi, J. N. (2005). Rethinking procrastination: Positive effects of "active" procrastination behavior on attitudes and performance. The Journal of Social Psychology, 145(3), 245-264. https://doi.org/10.3200/SOCP.145.3.245-264

Çokluk, Ö. (2010). Lojistik Regresyon Analizi: Kavram ve Uygulama. Kuram ve Uygulamada Eğitim Bilimleri/Educational Sciences: Theory \& Practice, 10(3), 1357-1407. http://www.academia.edu/download/32582073/logistik_regresyon_analizi.pdf

de Jong, N., Verstegen, D. M., Tan, F. E., \& O'Connor, S. J. (2013). A comparison of classromm and online synchronus problem-based learning for students undertaking statistics as part of a Public Health Masters degree. Advances in Health Sciences Education, 18, 245-264. https://doi.org/10.1007/s10459-012-9368-x

Delaval, M., Michinov, N., Le Bohec, O., \& Le Hénaff, B. (2017). How can students' academic performance in statistics be improved? Testing the influence of social and temporal-self comparison feedback in a web-based training environment. Interactive Learning Environments, 25(1), 35-47. https://doi.org/10.1080/10494820.2015.1090456

Doherty, W. (2006). An analysis of multiple factors affecting retention in Web-based community college courses. Internet \& Higher Education, 9, 245-255. https://doi.org/10.1016/j.iheduc.2006.08.004

Elsworth, D. H. (2009). Motivation in Education. New York, NY, USA: Nova.

Elvers, G. C., Polzella, D. J., \& Graetz, K. (2003). Procrastination in online courses: Performance and attitudinal differences. Teaching of Psychology, 30(2), 159-162. https://doi.org/10.1207/S15328023TOP3002_13

Gafni, R., \& Geri, N. (2010). Time management: Procrastination tendency in individual and collaborative tasks. Interdisciplinary Journal of Information, Knowledge, and Management, 5, 115-125. http://www.ijikm.org/Volume5/IJIKMv5p115-125Gafni448.pdf

Geri, N., Gafni, R., \& Winer, A. (2014). The u-curve of e-learning: course website and online video use in blended and distance learning. Interdisciplinary Journal of E-Learning and Learning Objects, 10, 1-16. http://www.ijello.org/Volume10/IJELLOv10p001-016Geri0473.pdf

Gilbert, N., Burns, J., Djira, G. D., Koch, K., \& Bott, R. C. (2016). Evaluation of the Effects of Online Case Studies in an Equine Nutrition Course on Student Performance, Procrastination and Satisfaction. NACTA Journal, 60(2), 242.

Hong, E., \& Milgram, R. M. (2000). Homework: Motivation and learning preference. Westport, CT: Bergin Garvey.

Hosmer, D. W. Jr., \& Lemeshow, S. (2000). Applied Logistic Regression ( $2^{\text {nd }}$ Edition), New York: John Wiley \& Sons. https://doi.org/10.1002/0471722146

King, J. E. (2008). Binary Logistic Regression. in ed J. W. Osborne., Best Practices in Quantitative Methods. SAGE. https://doi.org/10.4135/9781412995627.d29

Klassen, R. M., Krawchuk, L. L., \& Rajani, S. (2008). Academic procrastination of undergraduates: Low self-efficacy to self-regulate predicts higher levels of procrastination. Contemporary Educational Psychology, 33, 915-931. 
https://doi.org/10.1016/j.cedpsych.2007.07.001

Klingsieck, K. B., Fries, S., Horz, C., \& Hofer, M. (2012). Procrastination in a distance university setting. Distance Education, 33(3), 295-310. https://doi.org/10.1080/01587919.2012.723165

McElroy, B. W., \& Lubich, B. H. (2013). Predictors of course outcomes: early indicators of delay in online classrooms. Distance Education, 34(1), 84-96. https://doi.org/10.1080/01587919.2013.770433

Michinov, N., Brunot, S., Le Bohec, O., Juhel, J., \& Delaval, M. (2011). Procrastination, participation, and performance in online learning environments. Computers \& Education, 56, 243-252.

https://doi.org/10.1016/j.compedu.2010.07.025

Moon, S. M., \& Illingworth, A. J. (2005). Exploring the dynamic nature of procrastination: A latent growth curve analysis of academic procrastination. Personality and Individual Differences, 38. https://doi.org/10.1016/j.paid.2004.04.009

Moore, M. G., \& Kearsley, G. (2011). Distance Education: A Systems View of Online Learning. Cengage Learning.

Onwuegbuzie, A. J. (2004). Academic procrastination and statistics anxiety. Assessment \& Evaluation in Higher Education, 29(1), 3-19. https://doi.org/10.1080/0260293042000160384

Palcroft, L. B., \& Lopez, M. V. (2009). Personality Assessment: New Research. New York, NY, USA: Nova.

Pallant, J. (2007). SPPS Survival Manual. A Step by Step Guide to Data Analysis Using SPSS for Windows $\left(3^{\text {rd }}\right.$ Ed.), England: Open University Press//McGraw-Hill.

Perrin, C. J., Miller, N., Haberlin, A. T., Ivy, J. W., Meindl, J. N., \& Neef, N. A. (2011). Measuring and reducing college students' procrastination. Journal of Applied Behavior Analysis, 44(3), 463-474. https://doi.org/10.1901/jaba.2011.44-463

Pychyl, T. A., Morin, R. W., \& Salmon, B. W. (2000). Procrastination and the planning fallacy: An examination of the study habits of university students. Journal of Social Behavior and Personality, 16, 135-151. http://search.proquest.com/openview/fd4a18b2e292fb8b354319ee12e658b1/1?pq-origsite=gscholar\&cbl=1819046

Rakes, G. C., \& Dunn, K. E. (2010). The Impact of Online Graduate Students' Motivation and Self-Regulation on Academic Procrastination. Journal of Interactive Learning, 9(1), 78-94. http://www.ncolr.org/jiol/issues/pdf/9.1.5.pdf

Romano, J., Wallace, T. L., Helmick, I. J., Carey, L. M., \& Adkins, L. (2005). Study procrastination, achievement, and academic motivation in web-based and blended distance learning. Internet and Higher Education, 8, 299-305. https://doi.org/10.1016/j.iheduc.2005.09.003

Schouwenburg, H. C., \& Groenewoud, J. T. (2001). Study motivation under social temptation: Effects of trait procrastination. Personality and Individual Differences, 30, 229-240. https://doi.org/10.1016/S0191-8869(00)00034-9

Scouller, K. (1998). The influence of assessment method on students' learning approaches: Multiple choice question examination versus assignment essay. Higher Education, 35, 453-472. https://doi.org/10.1023/A:1003196224280

Steel, P. D. (2002). The Measurement and Nature of Procrastination. Unpublished Dostoral Dissertation. University of Minnesota. http://search.proquest.com/docview/276586835?pq-origsite=summon

Steel, P. D. (2007). The nature of procrastination: A meta-analytic and theoretical review of quintessential self-regulatory failure. Psychological Bulletin, 133(1), 65-94. https://doi.org/10.1037/0033-2909.133.1.65

Stewart, M., Stott, T., \& Nuttall, A. M. (2016). Study goals and procrastination tendencies at different stages of the undergraduate degree. Studies in Higher Education, 41(11), 2028-2043. https://doi.org/10.1080/03075079.2015.1005590

Thatcher, A., Wretschko, G., \& Fridjhon, P. (2008). Online flow experiences, problematic Internet use and Internet procrastination. Computers in Human Behavior, 24, 2236-2254. https://doi.org/10.1016/j.chb.2007.10.008

Tuckman, B. W. (2002). Academic procrastinators: Their rationalizations and Web-course performance. 110th Annual Meeting of the American Psychological Association. Chicago, Illinois. http://files.eric.ed.gov/fulltext/ED470567.pdf

Tuckman, B. W. (2005). Relations of Academic Procrastination, Rationalizations, and Performance in a Web Course with Deadlines. Psychologzcal Reports, 96(3c), 1015-1021. https://doi.org/10.2466/PR0.96.4.1015-1021

Uzun Özer, B., Demir, A., \& Ferrari, J. R. (2009). Exploring Academic Procrastination Among Turkish Students: 
Possible Gender Differences in Prevalence and Reasons. The Journal of Social Psychology, 149(2), 241-257. https://doi.org/10.3200/SOCP.149.2.241-257

Uzun, Ö. B. (2009). Bir Grup Lise Öğrencisinde Akademik Erteleme Davranışı: Sıklığı, Olası Nedenleri Ve Umudun Rolü. Türk Psikolojik Danışma ve Rehberlik Dergisi, 4(32), 12-19. http://dergipark.ulakbim.gov.tr/tpdrd/article/viewFile/1058000085/1058000087

Yamada, M., Goda, Y., Matsuda, T., Kato, H., \& Miyagawa, H. (2015). The Relationship Among Self-Regulated Learning, Procrastination, And Learning Behaviors In Blended Learning Environment. 12th International Conference on Cognition and Exploratory Learning in Digital Age 2015, 67-74. Greater Dublin, Ireland. http://eric.ed.gov/?id=ED562147

Yamada, M., Goda, Y., Matsuda, T., Saito, Y., Kato, H., \& Miyagawa, H. (2016). How does self-regulated learning relate to active procrastination and other learning behaviors? Journal of Computing in Higher Education, 28(3), 326-343. https://doi.org/10.1007/s12528-016-9118-9

You, J. W. (2015). Examining the Effect of Academic Procrastination on Achievement Using LMS Data in e-Learning. Educational Technology \& Society, 18(3), 64-74. http://www.ifets.info/journals/18_3/5.pdf

\section{Copyrights}

Copyright for this article is retained by the author(s), with first publication rights granted to the journal.

This is an open-access article distributed under the terms and conditions of the Creative Commons Attribution license which permits unrestricted use, distribution, and reproduction in any medium, provided the original work is properly cited. 